Waal, B.M.E. de, Breman, P., Batenburg, R. Do individual characteristics matter? The quality of work during the implementation of a workflow management system in a Dutch social insurance company. International Journal of Business Information Systems: 2012, 11(1), 1-21

\begin{tabular}{|l|l|}
\hline $\begin{array}{l}\text { Postprint } \\
\text { Version }\end{array}$ & 1.0 \\
\hline Journal website & $\underline{\text { http://www.ingentaconnect.com/content/ind/iibis/2012/00000011/00000001/art00 }}$ \\
\hline Pubmed link & $\underline{001}$ \\
\hline DOI & $10.1504 /$ JBIS.2012.048339 \\
\hline
\end{tabular}

This is a NIVEL certified Post Print, more info at http://www.nivel.eu

\title{
Do individual characteristics matter? The quality of work during the implementation of a workflow management system in a Dutch social insurance company
}

\author{
BENNY M.E. DE WAAL* AND PAUL BREMAN \\ Research Centre for Innovation and Business, University of Applied Sciences Utrecht, P.O. \\ Box 85029, 3508 AA Utrecht, The Netherlands E-mail: benny.dewaal@hu.nl E-mail: \\ paul.breman@hu.nl *Corresponding author
}

\section{RONALD BATENBURG}

Netherlands Institute for Health Services Research, NIVEL, P.O. Box 1568, 3500 BN Utrecht, The Netherlands and Institute of Information and Computing Science, Utrecht University, P.O. Box 80089, 3508 TB Utrecht, The Netherlands E-mail: r.batenburg@nivel.nl

\begin{abstract}
:
Do individual characteristics influence how the quality of work is related to the use of a workflow management system (WFM) in a Dutch social insurance organisation? This key question is addressed in this paper. Building upon DeLone and McLean's model, we investigated the effects of gender, age, education, system experience and computer skills on the relationship between the level of user satisfaction with a WFM system and the perceived quality of work. The expected effects of individual characteristics were tested using survey data collected from 143 end users of a large Dutch social insurance organisation that recently deployed a WFM system. The results of the regression analysis show that: 1 user satisfaction has a positive relationship with quality of work 2 age has a significant moderating influence on the perceived quality of work 3 gender and system experience have no moderating effects 4 education and system computer skills (as individual characteristics) had a degree of moderating effects.

These results imply that it is valuable to focus on older employees when deploying information technology as WFM systems, i.e., by improving their computer skills in particular.
\end{abstract}


Waal, B.M.E. de, Breman, P., Batenburg, R. Do individual characteristics matter? The quality of work during the implementation of a workflow management system in a Dutch social insurance company. International Journal of Business Information Systems: 2012, 11(1), 1-21

Reference to this paper should be made as follows: De Waal, B.M.E., Breman, P. and Batenburg, R. (2012) 'Do individual characteristics matter? The quality of work during the implementation of a workflow management system in a Dutch social insurance company', Int. J. Business Information Systems, Vol. 11, No. 1, pp.1-21.

Biographical notes: Benny M.E. De Waal is Lecturer and Researcher of the Research Centre for Innovation and Business at the University of Applied Science Utrecht. He obtained his Bachelor of Applied Sciences at the University of Applied Science Breda and his Masters of Art at Tilburg University. Formerly, he was employed as a Researcher at Eindhoven University, the Netherlands. His focus is on information systems and quality of work, and on user participation in the process of development and implementation.

Paul Breman is a Professor of Organising Innovation at the HU Utrecht Business School in the Netherlands. He is also a Senior Management Consultant at Twynstra Gudde Management Consultants in the Netherlands. He received his $\mathrm{PhD}$ in Business Administration at Henley Business School at the University of Reading, where he still is affiliated for the doctoral programme.

He is also lecturing at Karlsruhe University of Applied Sciences, the Open University and the Institute of Social Studies of Erasmus University. He has many years' experience as a Consultant, Manager, Researcher, Lecturer, Trainer and Executive Coach and has many publications in journals and books on his name. He is a Reviewer of the Journal of Small Business Management, the Journal of Multidisciplinary Research and member of the editorial board of the Dutch M\&O (Management \& Organization) Journal.

Ronald Batenburg is an Associate Professor in Information and Computing Sciences, Utrecht University. Since 2009, he is also Programme Coordinator healthcare and manpower planning at NIVEL, Netherlands Institute for healthcare research. He received his $\mathrm{PhD}$ at Groningen University, the Netherlands, and was formerly employed as an Assistant Professor at Tilburg University and Nijmegen School of Management. Recently, his focus is on how IT adoption and implementation can improve healthcare organisations and professions.

\section{INTRODUCTION}

There is a long tradition of research on the relationship between information systems and information technology (IS/IT) and quality of work. Retrospectively, five phases of schools of thought can be distinguished.

The first phase can be recognised between 1950 to 1970, and can be labelled as the era of technological determinism. According to this perspective, technology was seen as a direct determinant of the quality of work. Organisations are designed according to the predominant form of technology, and so is the organisation of work (Blauner, 1964; Burns and Stalker, 1961). During the second phase, which occurred between 1970 to 1980, technology was considered as a management tool, used to increase the level of control over employees (Braverman, 1974; Kern and Schumann, 1984). This 
Waal, B.M.E. de, Breman, P., Batenburg, R. Do individual characteristics matter? The quality of work during the implementation of a workflow management system in a Dutch social insurance company. International Journal of Business Information Systems: 2012, 11(1), 1-21

phase can be labelled as the era in which the idea of socio-political determinism was dominant; technology was considered as instrumental in the enforcement of labour relations and power distances within organisations. Due to the emergence of IT, the third phase (1980 to 1990) can be recognised as a period in which technology was seen as providing an opportunity to redesign the ways in which work was organised (Child, 1972; Zuboff, 1984). Technology was seen as an enabler of organisational redesign, which is not an automatic process, but dependent on choices made by the management ('organisational choice'). The next phase, between 1990 and 2000, can be described as a period of organisational conservatism. In this phase, it was recognised that technology has the potential to change and to develop work processes, but in practise, the results were disappointing due to inertia and the unruliness of classic organisational structures (Bos, 2000). During the final and most recent period, from 2000 onwards, the idea of IS/IT as an 'enabler' of work and organisational (re)design has been revitalised. The central idea is now that the design of work results from the interconnection between IS/IT design and organisational design, as expressed in the concept of 'business-IT alignment' (cf., Chan and Reich, 2007; Silvius et al., 2009). In addition, mutual shaping drives the (intended) use of and satisfaction with IS/IT and its effect on the quality of work (Barut and Dogerlioglu, 2010; Batenburg and Koopman, 2010; Benders et al., 2000; Daim et al., 2010; Lawler et al., 2011).

As of now, the relationship between satisfaction with IS/IT and quality of work is crucial, as the use of computers in factories and offices is predominant in most developed countries (Smulders, 2006). For instance, it appears that $63 \%$ of workers in the Netherlands work at least one hour a day with computers. About $17 \%$ work behind a computer for between 6 to 8 hours every day. On the other hand, it has been observed that not every employee possesses the required computer skills or digital competences necessary to work with IS/IT (Van Vuuren et al., 2006). In this respect, inequality can exist between people of different ages, gender and with different levels of education. This may be related to the fact that complex, computerised and autonomous work, as well as high work pressure, is mainly found in modern organisations.

Thus far, research has been conducted on either the relationship between work and the use of and satisfaction with IS/IT (cf., Andries et al., 2002; Bijleveld et al., 2000; Carayon, 1997; Kamhawi and Gunasekaran, 2009; Kanji and Chopra, 2009; Keramati and Behmanesh, 2010; Lucas and Spitler, 1999; Medcof, 1996; Newton and Jimmieson, 2009; Orlikowski and Baroudi, 1991; Ramayah et al., 2007; Steijn, 2001), or the relationship between individual characteristics and the use of and satisfaction with IS/IT (cf., Agarwal and Prasad, 1999; Gefen and Straub, 1997; Venkatesh et al., 2003; Ward et al., 2005; Webster and Martocchio, 1992). In this study, we will take these streams of research as a starting point from which to investigate the relationship between user satisfaction and quality of work, and the stability of this relationship according to individual characteristics (i.e., gender, age, education, etc.).

In this paper, the relationship between satisfaction with IS/IT and quality of work, in relation to individual characteristics, will be empirically addressed with regard to the implementation of a workflow management (WFM) system in a social insurance company in the Netherlands. In the following sections, the theoretical perspective of this study will be described, including the hypotheses which are proposed. In the 
Waal, B.M.E. de, Breman, P., Batenburg, R. Do individual characteristics matter? The quality of work during the implementation of a workflow management system in a Dutch social insurance company. International Journal of Business Information Systems: 2012, 11(1), 1-21

subsequent section, the context of an empirical case study of the end users of the WFM system is presented. The collected data are described, explained and analysed in order to test the hypotheses. After the results, we will close this paper with the conclusions and limitations of this research.

\section{THEORETICAL PERSPECTIVES}

A wide range of models have been developed in order to study the use and acceptance of IS/IT, such as the diffusion of innovations (DoI) theory, the theory of reasoned action (TRA), the technology acceptance model (TAM), the theory of planned behaviour (TPB), the task-technology fit model (TTF), and the unified theory of acceptance and use of technology (UTAUT) (cf., Dwivedi et al., 2008; Venkatesh et al., 2003). The basic concepts underlying these models are based on the individual's reaction to using IS/IT, which can lead to the intended or actual use of IT. In these models, (intended or actual) use is the dependent variable, along with constructs such as perceived usefulness, perceived ease of use, attitude towards the system, and the subjective norm, which is the independent variable. For the study of the relationship between IS/IT use and quality of work, however, these models are inadequate. The limitations of these models are first, their focus on IS/IT use, and second, the absence of a relationship between individual and organisational benefits. The missing link is the inclusion of the direct determinants and measurements of the success (or failure) of IS/IT in terms of creating and using IS/IT and the effects of this. In this way, a IS/IT success measure (i.e., user satisfaction) can be linked to individual benefits, such as quality of work. A leading study in this area, and the most frequently cited model in research into the success of IS/IT, is DeLone and McLean's (D\&M) model of IS success (DeLone and McLean, 1992, 2003). Their model represents IS/IT success through six interdependent constructs:

1. quality of information (e.g., completeness, ease of understanding and relevance)

2. system quality (e.g., usability, availability and reliability)

3. service quality (e.g., the empathy and responsiveness of the IT department)

4. use (intended or actual)

5. user satisfaction

6. net benefits (such as quality of work).

The authors assume that there is an association between these constructs in terms of process. In other words, quality constructs will directly affect IS/IT use and user satisfaction. They assume that use and satisfaction are directly related, and hence that if users have a positive experience of IS/IT, this will lead to increased user satisfaction.

Similarly, increased user satisfaction will lead to increased use of IS/IT. As a result of this, the individual benefits of IS/IT use may accumulate, improving productivity, and finally providing organisational benefits. Descending from the organisational to the individual level, these benefits will eventually reinforce the use of IS/IT and end users' satisfaction with IS/IT. According to the D\&M model, IS/IT use precedes user satisfaction in terms of process, but positive experiences of IS/IT use will also lead to increased user satisfaction in a causal sense.

Although it is possible to take both IS/IT use and user satisfaction as starting points from which to investigate their relationship with quality of work, we will focus only on user satisfaction. The reasons for this are twofold. First, the use of the WFM was 
Waal, B.M.E. de, Breman, P., Batenburg, R. Do individual characteristics matter? The quality of work during the implementation of a workflow management system in a Dutch social insurance company. International Journal of Business Information Systems: 2012, 11(1), 1-21

strongly mandatory. Therefore, in this situation, IS/IT use as such becomes an irrelevant factor, and only loosely related with the end-user's appreciation of the system. For instance, we can expect that although the WFM system was used frequently, the end-users were dissatisfied; and vice versa. The second reason is that WFM systems, by definition, have a significant impact on the work processes of end users. WFM systems are specifically designed to automate work and processes, by steering and determine the activities to perform. This inevitably will have influence on the quality of work (De Waal and Batenburg, 2008; Holden et al., 2011; Morris and Venkatesh, 2010; Ngai et al., 2005; Poelmans, 2002; Wilkin, 2007; WilsonEvered and Härtel, 2009; Zur Muehlen, 2004).

For these reasons we focus on how user satisfaction has an impact on one's perceived quality of work, not IS/IT use. If WFM systems are implemented they become an integral part of the work process of hence of the quality of the end-users job. This becomes clear when WFM systems dictate the amount of work, and take over the job control. Then this may result in more workload and less autonomy but necessarily, as this will - in the end - actually dependent on the system is experienced by the end-use himself. This can go both ways, but primarily we assume that a positive user satisfaction has a positive impact on quality of work. This is formulated in the following hypothesis: Hypothesis 1 For WFM-systems, it will show that the user satisfaction of end-users has a positive relationship with their perceived quality of work.

In addition to the D\&M model, we aim to explore how individual characteristics will influence the assumed relationship between user satisfaction and quality of work. These research aims are depicted in Figure 1.

\section{[FIGURE 1]}

In order to translate this conceptual model into an empirical measurement model, several existing concepts and instruments were used.

Several studies have been performed in order to measure user satisfaction (Azadeh et al., 2009; Etezadi-Amoli and Farhoomand, 1996; Igbaria and Tan, 1997; Kim, 2009; Seddon and Kiew, 1996; Shaw et al., 2002). For user satisfaction, we will refer to the work of Shaw et al. (2002). Their study showed how the information satisfaction of individual users can be measured, and how service satisfaction can be measured as an important determinant of IS/IT preference and appreciation. Quality of work can be defined and measured in several ways. One of the frameworks which is often used is based on the so-called socio-technical systems theory (Benders et al., 2000; DeJoy et al., 2010; De Sitter et al., 1997; Gittell et al., 2010; Nabitz et al., 2009). According to this theory, the quality of work is dependent on how jobs and organisations are designed according to certain principles. These principles are based on the attempt to maintain a balance between problems in the work environment ('need for control') and the possibility of dealing with these problems ('control capacity'). This implies that control capacity should be located where the need for control appears. In this respect, socio-technically designed organisations enable employees to perform not just one small, monotonous task as part of a large production process (as in 'Taylorised' organisations), but should instead enable them to perform a coherent set of tasks within a production cycle (cf., Schouteten, 2001). In order to empirically define the concept of the quality of working life, one can apply Karasek's (1979) job demands model and Hacker's (1989) concept of 'complete tasks'. A complete job 
Waal, B.M.E. de, Breman, P., Batenburg, R. Do individual characteristics matter? The quality of work during the implementation of a workflow management system in a Dutch social insurance company. International Journal of Business Information Systems: 2012, 11(1), 1-21

consists of a coherent set of tasks which have been executed, prepared and supported, at varying levels of difficulty in order to offer opportunities to learn on the job (selfdevelopment).

As this study is specifically focussed on the use and the effects of a WFM system, some adaptations to the conceptual model and measurements as described above need to be made. WFM systems are designed to coordinate processes and to make work more efficient by improving the provision of information and steering for tasks and roles.

WFM systems, therefore, potentially affect the autonomy and workload of users. Both elements of the quality of work are essential, as related research has shown that an increasing number of organisations are giving their employees more autonomy in their jobs (Hardwick and Salaff, 2003). Therefore, we have chosen to first focus on autonomy and workload as the main indicators of the quality of work of WFM end users. These characteristics are defined as:

1. Workload: The degree to which the worker is working at a very high speed and working to tight deadlines.

2. Autonomy: The degree to which the worker is able to decide upon the pace, order and methods involved in his or her work.

With regard to the individual characteristics of the end users, the literature points to various characteristics that can be used to investigate these individual differences in relation to IS/IT use and appreciation. These individual differences, in the case of WFM end users, may similarly influence their attitudes towards the system and their readiness to use IT/IS. Therefore, this may have an impact on their perceived quality of work (Carayan and Karsh, 2000; Freudenthal, 2001; Gillard et al., 2007; Roach et al., 2011; Shaw and Gant, 2002; Ugrin, 2009; Zauchner et al., 2000).

In the section below, we will summarise how individual characteristics such as gender, age, education, system experience, and (system) computer skills are related to IS/IT use and satisfaction, according to the literature.

\subsection{Gender}

In their paper, Gillard et al. (2007) studied the relationship between gender and IT acceptance. Their conclusion was that gender has no relationship with IT acceptance and competencies, but that it is relevant to the ways in which certain (less powerful and less privileged) groups in society are excluded from the socioeconomic mainstream. Shaw and Gant (2002) studied the differences between men and women in terms of internet use and found no gender differences. The same is true for Zauchner et al. (2000), who studied the effects of IT implementation on men and women, but did not find any gender differences. Roach et al. (2011) found that men were more influenced by the technology itself and women by social factors. In addition, women had significantly lower computer self-efficacy (CSE) and higher computer anxiety than men. In a study of students using asynchronous communication technology, Im et al. (2008) found that gender had a moderating effect. The effects of perceived usefulness on the intention to use was slightly stronger for males, and the effects of perceived ease of use on the intention to use was slightly stronger for women. Venkatesh et al. (2003), in their review of eight user acceptance models, found that gender, age and experience had moderating effects on usage measures. Johnson and Marakas (2000) and Torkzadeh et al. (1999) found that gender had no effect on CSE, an individual self-assessment of one's ability to use a computer. Ahuja and Thatcher (2005) found gender effects in the 
Waal, B.M.E. de, Breman, P., Batenburg, R. Do individual characteristics matter? The quality of work during the implementation of a workflow management system in a Dutch social insurance company. International Journal of Business Information Systems: 2012, 11(1), 1-21

relationship between autonomy, work overload and trying to innovate using IT. For men, they found a significant direct effect of qualitative overload as well as a significant interaction effect with autonomy. For women, similar results were found for quantitative overload. Finally, gender differences were found by Venkatesh and Morris (2000) with regard to individuals' adoption and voluntary usage of technology in the workplace. The usage behaviour of 342 workers from five organisations was studied over a five-month period as they were being introduced to a new software system.

\subsection{Age}

Freudenthal (2001) studied the relationship between age and individuals' performance in information retrieval tasks, and found that older end users were slower and had more problems in the retrieval tasks than younger end users. Ha et al. (2007) investigated the moderating effects of gender, age and prior experience on game adoption. Ha et al.

(2007) found that age was a key moderator in game acceptance. Scott and Walczak (2009) found no direct effects of age, gender or experience on CSE. The participants in this study were relatively young and high-achieving college students. This could be the reason why no effects were found. Other studies have consistently reported relationships between age and IS/IT use and appreciation. Older users perceive new IS/IT as being less useful and difficult to learn, and are unwilling to use unfamiliar technologies (Gomez et al., 1986; Nickel and Pinto, 1986).

\subsection{Education}

Zmud (1979) has already concluded, after an empirical review of the relevant literature, that users' level of education influences their success in using IS/IT. Burton-Jones and Hubona (2006) found that education had no direct effects on the application of e-mails and the usage of a word processing application. Their study was conducted by 125 members of staff and professional employees in a large government agency in the USA.

Of the respondents, 122 had used the e-mail application, and 118 had used the word processing application.

\subsection{System experience and system computer skills}

Carayan and Karsh (2000) showed that previous experience with computers and system skills with imaging technology had positive effects on the level of use and the ability of end users. Im et al. (2008) found that experience had no moderating effects on communication technology. On the other hand, Kim (2008) found that experience had a moderating effect. In this study on the use of mobile wireless technology among adult workers, the effect of the company's willingness to fund this technology was related to intention to use, while prior experience had a moderating effect. Experience was also investigated in an extensive study by Mao and Palvia (2008). A total of 757 employees from companies in metropolitan areas of China responded to a survey which asked them to recall the month and year when they first adopted email. The results showed that more experienced users had more positive perceptions, attitudes and behavioural intentions.

Experience directly affected the usage of Object Oriented technology by 154 IT professionals in four mid-western states in the USA (Lee et al., 2006). Burton-Jones and Hubona (2006) found that system experience had a direct effect on the volume and frequency of usage of an e-mail application. 
Waal, B.M.E. de, Breman, P., Batenburg, R. Do individual characteristics matter? The quality of work during the implementation of a workflow management system in a Dutch social insurance company. International Journal of Business Information Systems: 2012, 11(1), 1-21

These studies show that individual characteristics can sometimes have a direct effect, sometimes a moderated effect, and sometimes no effect. A great deal depends on the technology and the individual characteristics studied. Furthermore, no evidence has been found to suggest what effect individual characteristics have on the relationship between user satisfaction and quality of work. In this study, we will explore what this effect could be. In line with the basic hypothesis formulated earlier, we expect that individual characteristics will have no effect on the relationship between user satisfaction and quality of work. This is formulated in the following hypothesis: Hypothesis 2 Individual characteristics will have no effect on the relationship between user satisfaction and quality of work.

\section{CONTEXT: A DUTCH SOCIAL INSURANCE COMPANY}

The case study which was used to test and validate the previous hypotheses was performed within a Dutch organisation for the delivery of employee insurance. The organisation is an independent policy agency that reports to the Dutch Ministry of Social Affairs. This organisation controls all of the administrative and financial processes involved in the execution of social security laws, and is dedicated to controlling misuse and fraud. Their second task is to realise the reintegration of (partially) unemployed and disabled employees. For this task, the organisation cooperates with private healthcare companies. During this study in 2008, the organisation had 15,834 employees (13,332 fte) under contract.

In such organisations WFM plays an important role to monitor and control the work processes. The work process consists of lengthy procedures, in which several employees are involved and must interact with the WFM system to do their job. Also, the number of cases which is covered, is very large. In 2008, the number was 41,000 . Therefore, this organisation offers a great opportunity to test our hypothesis. The data collection took place within the claims department, which is part of the division of 'suitability for employment'. This division is divided into six regions. The focus of the claims department is to examine clients' medical and work-based capabilities and to judge their claims within the scope of the national laws. This department includes over 6,000 employees.

In 2007, the Dutch organisation for the delivery of employee insurance introduced a new system in order to support the front office and to integrate existing applications. As an important part of this event, a WFM system was initiated. This WFM system was primarily aimed at streamlining the core administrative processes of the social security laws within the claims organisation, and at improving quality in terms of the company's compliance with (mostly legal) rules and procedures. This system was specifically meant to support the transition of information and tasks from one 'resource' to another.

In addition to achieving greater efficiency and a higher quality of services, the goal of the WFM project was to achieve uniformity in case handling as well. To support this aim, the concept of teamwork was introduced. Teams were created by joining together people from four different types of job categories: team-support employees; process support employees; work/job consultants; and medical insurance doctors. 
Waal, B.M.E. de, Breman, P., Batenburg, R. Do individual characteristics matter? The quality of work during the implementation of a workflow management system in a Dutch social insurance company. International Journal of Business Information Systems: 2012, 11(1), 1-21

\section{RESEARCH METHOD}

\subsection{Data collection}

Data collection took place at six offices within the claims department. It involved a survey of employees from four different job categories, within six to 12 months after the WFM system was implemented. The measurement was carried out in different phases over the locations and took place in May to June 2008. Within these locations, the sampling was stratified according to the four main job categories of employees who would become team members and the main users of the system. The questionnaire was sent out via the internet. It transpired that not all of the team support and process support employees had internet access. For this group, specific solutions were designed, such as completing the questionnaire on a different computer or providing them with a paper version of the questionnaire.

\subsection{Description of the research group}

There was a total of 143 respondents, indicating a response rate of 30\% that was not biased according to job categories as the main stratification criterion. The sample consisted of team support employees (13\%), process support employees (21\%), job consultants (42\%) and medical insurance doctors (24\%), which meant that the sample was largely representative of the organisation as a whole. Of the respondents, $60.1 \%$ were male and $39.9 \%$ were female. The average age was 48.5 years old (ranging from 22 to 65 years old). The respondents had been employed for an average of 19 years, and this ranged from one to 41 years. Of the respondents, 35.7\% indicated that they had better computer skills than their colleagues. Slightly more than half of the respondents stated that they had average computer skills. Regarding the WFM system, $25.9 \%$ of the respondents stated that they had better than average computer skills. Finally, 27.3\% of the respondents held a university degree.

\subsection{Operationalisation of constructs}

In order to measure the level of user satisfaction, the information satisfaction and service satisfaction scales developed by Shaw et al. (2002) were used. A great deal of empirical research has been done on the acceptance and validation of measurements of quality of work (cf., Josten and Ester, 2005; Karasek, 1979, Karasek and Theorell, 1990; Smulders, 2006; Schouteten, 2001). For the Netherlands, the NOVA-WEBA and VBBA models (Dhondt et al., 2002; Schouteten and Benders, 2004) are the leading instruments for measuring quality of work and have been applied for over 20 years. For this study, the scales of workload and autonomy were used to measure the quality of work. All of the items on the four scales were measured using a four-point scale with the end points of 'strongly agree (4)' and 'strongly disagree (1)'. The individual characteristics were measured as follows:

- gender ( 1 = male, 2 = female)

- age (in years)

- education: 1 secondary education 2 vocational education 3 bachelor's degree 4 master's degree.

- system experience (in months)

- system computer skills, measured on a five-point scale with the end points of 'much greater than average (5)' and 'much less than average (1)'. 
Waal, B.M.E. de, Breman, P., Batenburg, R. Do individual characteristics matter? The quality of work during the implementation of a workflow management system in a Dutch social insurance company. International Journal of Business Information Systems: 2012, 11(1), 1-21

\subsection{Instrument validation}

Factor analysis was first performed in order to analyse the construct validity of the group of eight items measuring user satisfaction. Principal component analysis (PCA) with Promax rotation resulted in a two-factor solution with eigenvalues of 4.26, and 1.69, accounting for 53.2\% (resp. 21.1\%) of the overall variance. As shown in Table 1, the eight items were distinctively loaded on one of the two constructs. This indicates appropriate discriminant validity. The reliability of the two scales, the four-item information satisfaction scale (F05 to F08) and a four-item service satisfaction scale (F01 to F04), was confirmed by Cronbach's alpha values of 0.92 and 0.84 respectively.

Next, a similar PCA with Promax rotation for the quality of work showed that the 14 items contributed to a two-factor solution with eigenvalues of 4.93 and 2.89. The overall variance which was accounted for by the two-factor solution was $35.2 \%$ and $20.7 \%$ respectively. Table 2 shows that the 14 items were almost exclusively loaded onto one of the constructs, (again) indicating good discriminant validity. Cronbach's alpha values were calculated for the two item sets (Q01 to Q07 and Q08 to Q14). The reliability of the scales was confirmed by Cronbach's alpha values of 0.88 and 0.83 respectively for the workload and autonomy constructs. A summary of the basic statistics is given in Table 3 .

\section{[TABLE 1, TABLE 2, TABLE 3]}

\section{RESUlTS}

The basic hypothesis, as defined by our research model, concerns the relationship between user satisfaction and quality of work. Assuming linearity, we primarily assumed that individual characteristics (i.e., gender, age, education, system experience and system computer skills) act purely as moderators, influencing the shape of the relationship between user satisfaction and quality of work (cf., Sharma et al., 1981). This implies that the regression model can be written as:

$$
\begin{gathered}
\text { Quality_of_Work }=\alpha+\beta_{1} \text { User_Satisfaction }+\beta_{2} \text { User_Satisfaction } \\
\times \text { Ind_Characteristic }+\varepsilon
\end{gathered}
$$

According to this equation, it is expected that the main effect of user satisfaction ( $\beta$ ${ }^{1}$ ) will be significant. However, we have also explored whether the interaction effect between user satisfaction and individual characteristics ( $\beta^{2}$ ) has an additional (net) significant effect according to the second hypothesis formulated. Before presenting the subsequent results of the regression analyses, it should be mentioned that both the dependent variables (workload and autonomy) and the independent variables (information satisfaction and service satisfaction) were normally distributed. Tests showed that the error terms in the regression models were normally distributed, and that they were not significantly correlated with the predictors, showing that there were no problems with heteroscedascity. The results of the tests of our expectations regarding the relationship between user satisfaction, quality of work and individual characteristics are shown in the following sub-sections. 
Waal, B.M.E. de, Breman, P., Batenburg, R. Do individual characteristics matter? The quality of work during the implementation of a workflow management system in a Dutch social insurance company. International Journal of Business Information Systems: 2012, 11(1), 1-21

\subsection{Gender}

From Table 4, we can conclude that information and service satisfaction has a negative and significant effect on workload. Furthermore, service satisfaction has a positive significant effect on autonomy. The interaction effect of gender is not significant, according to our hypothesis. This means that gender does not influence the form of the relationship between user satisfaction and quality of work.

\section{[TABLE 4]}

\subsection{Age}

The conclusion which can be drawn from Table 5 is that information and service satisfaction has a negative and significant effect on workload and a positive and significant effect on autonomy. Furthermore, the interaction effect of age is significant, except in the case of information satisfaction and autonomy (the p-value in this case is near .05). This means that age does influence the form of the relationship between user satisfaction and quality of work in the opposite direction as hypothesised. Older employees experience the effect of user satisfaction on workload and autonomy significantly more than younger employees.

\section{[TABLE 5]}

\subsection{Education}

As shown in Table 6, information and service satisfaction has a negative and significant effect on workload and a positive and significant effect on autonomy. Education only has a significant interaction effect with service satisfaction on autonomy. As a result, we can claim that education has no influence on the form of the relationship between user satisfaction and autonomy. This is in the expected direction. Education has no influence on the relationship between user satisfaction and quality of work.

\section{[TABLE 6]}

\subsection{System experience}

The conclusion which can be drawn from Table 7 is that information and service satisfaction has a negative and significant effect on workload and a positive and significant effect on autonomy. The interaction effect of system experience is not significant. This means that system experience does not influence the form of the relationship between user satisfaction and quality of work.

[TABLE 7]

\subsection{System computer skills}

From Table 8, we can conclude that service satisfaction alone has a negative and significant effect on workload. Furthermore, the additional effect of system computer skills is not significant. Therefore, system computer skills do not influence the form of the relationship between user satisfaction and quality of work. 
Waal, B.M.E. de, Breman, P., Batenburg, R. Do individual characteristics matter? The quality of work during the implementation of a workflow management system in a Dutch social insurance company. International Journal of Business Information Systems: 2012, 11(1), 1-21

\section{[TABLE 8]}

\subsection{Conclusions}

From the analysis, we can conclude that user satisfaction, the $\beta^{1}$ component, was in most cases significantly and negatively related to workload, and positively related to autonomy. This is consistent with Hypothesis 1. Furthermore, it appears that the size of the $\beta^{1}$ component varied. This indicates that individual characteristics have a degree of influence over the relationship between user satisfaction and quality of work, but not a systematic one. Second, we can conclude that most individual characteristics have no significant effect on the relationship between user satisfaction and quality of work. This result is consistent with the formulated hypothesis. Age alone had a significant effect on this relationship.

\section{CONCLUSIONS AND LIMITATIONS OF THE STUDY}

In this research, the moderating effects of individual characteristics were investigated in terms of the relationship between user satisfaction and quality of work, as perceived by individuals when using a WFM system. Data were gathered within a Dutch social insurance organisation, using validated scales to measure user satisfaction and quality of work, specifically with regard to the WFM system that had been recently implemented.

The main contribution of this study is that IS/IT satisfaction has a relationship with quality of work, but that this relationship is not moderated by individual characteristics, except age. The results show that there is a relationship between user satisfaction, measured in the form of information and service satisfaction, and quality of work, measured as workload and autonomy. The relationship between user satisfaction and perceived workload was negative, while the relationship with autonomy was positive.

Therefore, we concluded that user satisfaction has a positive influence on quality of work, but that this is dependent on the quality of work dimension used. Employees with higher user satisfaction experienced less workload and more autonomy, and visa versa.

This relationship between user satisfaction and quality of work was not moderated by most individual characteristics. Age alone had a moderating effect in this study. It was clearly shown that older users of the WFM system experienced a higher workload and less autonomy than younger users, when user satisfaction decreased. No differences were found between men and wthat the moderating effect of gender depends on the type of IS/IT and the constructs being measured (Burton-Jones and Hubona, 2006).

No moderating effects were found for education, system experience and system computer skills, with the exception of service satisfaction for autonomy. Apparently, for users with a higher degree of education, service satisfaction alone has an effect on autonomy. In addition, a greater degree of system experience had no effect on the relationship between user satisfaction and quality of work. One explanation for this result may be that during the implementation of the WFM system, disruptions caused the employees to keep working with the previous system in order to meet their targets. This resulted in a lack of use and experience with the new WFM system. As was mentioned earlier, the survey took place six to 12 month after the introduction of the WFM system. 
Waal, B.M.E. de, Breman, P., Batenburg, R. Do individual characteristics matter? The quality of work during the implementation of a workflow management system in a Dutch social insurance company. International Journal of Business Information Systems: 2012, 11(1), 1-21

Apparently, this was too short a time gap in these circumstances. The same explanation can be given for system computer skills.

The findings of this study have several implications for the use of IS/IT with regard to quality of work. First, there is evidence that some individual characteristics must be taken into account when introducing and using IS/IT. For older users, special attention must be given to providing information on service aspects of IS/IT. As shown in this study, user satisfaction is related to perceived quality of work in a stable manner. Subsequently, this improvement of quality of work may have consequences for employees' productivity, as illustrated in the literature on quality of work. Second, for users with a higher degree of education, it is also important to pay attention to the service aspects of IS/IT. When the service does not fulfil their expectations, they indicate experiencing less freedom to do their job. This can be especially true when using a WFM system, because of the high level of dependency on activities performed by these systems. Therefore, further research is needed in order to find the optimal form of IS/IT satisfaction for older users and users with a higher degree of education to experience an improvement in their quality of work as well.

There are, of course, also some limitations to this study. In this study, only one measurement was taken after the implementation of the WFM system. To prove that there is a causal relationship between user satisfaction and quality of work, a longitudinal design would be more appropriate. Second, the results were based on survey questions, which can provide only an indicative picture of the situation. More objective measurements of the variables used in this study can add cross-validation to support the results found. Finally, other aspects, such as system training conditions, management support and organisational changes, may have played a role in this assessment of the new WFM system.

\section{ACKNOWLEDGEMENTS}

The authors would like to thank the employees of the Social Insurance Company for their cooperation. Further, we would like to thank the reviewers for their comments and suggestions for improvement.

\section{REFERENCES}

Agarwal, R. and Prasad, J. (1999) 'Are individual differences germane to the acceptance of new information technologies?', Decision Sciences, Vol. 30, No. 2, pp.361-391.

Ahuja, M.K. and Thatcher, J.B. (2005) 'Moving beyond intentions and towards the theory of trying: effects of work environment and gender on post-adoption information technology use', MIS Quarterly, Vol. 29, No. 3, pp.427-459.

Andries, F., Smulders, P.G.W. and Dhondt, S. (2002) 'The use of computers among the workers in the European Union and its impact on the quality of work', Behaviour and Information

Technology, Vol. 21, No. 6, pp.441-447.

Azadeh, A., Sangari, M.S. and Songhori, M.J. (2009) 'An empirical study of the end-user satisfaction with information systems using the Doll and Torkzadeh instrument', International Journal of Business Information Systems, Vol. 4, No. 2, pp.324-339.

Barut, O. and Dogerlioglu, O. (2010) 'Human resources information systems: a sociotechnical perspective', Information Technology Journal, Vol. 9, No. 5, pp.877-888. 
Waal, B.M.E. de, Breman, P., Batenburg, R. Do individual characteristics matter? The quality of work during the implementation of a workflow management system in a Dutch social insurance company. International Journal of Business Information Systems: 2012, 11(1), 1-21

Batenburg, R. and Koopman, G. (2010) 'The conditional benefits of early user involvement at employee self-service applications in four Dutch ministries', International Journal of Business

Information Systems, Vol. 5, No. 2, pp.162-174.

Benders, J., Doorewaard, H. and Poutsma, E. (2000) 'Modern socio-technology: set by De Sitter', in Beyerlein, M.M. (Ed.): Work Teams: Past, Present, Future, pp.169-180, Kluwer Academic Publishers, Deventer.

Bijleveld, C.C.J.H., Andries, F. and Van Rijckevorsel, J.L.A. (2000) 'Positive and negative aspects of the work of information personnel: an exploratory analysis', Behaviour and Information

Technology, Vol. 19, No. 2, pp.125-138.

Blauner, R. (1964) Alienation and Freedom: The Factory Worker and its Industry, University of Chicago Press, Chicago.

Bos, R. ten (2000) Fashion and Utopia in Management Thinking, John Benjamins, Amsterdam.

Braverman, H. (1974) Labor and Monopoly Capital: The Degradation of Work in the Twentieth

Century, Monthly Review Press, New York.

Burns, T. and Stalker, G.M. (1961) The Management of Innovation, Tavistock, London.

Burton-Jones, A. and Hubona, G.S. (2006) 'The mediation of external variables in the technology acceptance model', Information \& Management, Vol. 43, No. 6, pp.706-717.

Carayan, P. and Karsh, B-T. (2000) 'Sociotechnical issues in the implementation of imaging technology', Behaviour \& Information Technology, Vol. 19, No. 4, pp.247-262.

Carayon, P. (1997) 'Temporal issues of quality of working life and stress in human-computer interaction', International Journal of Human-Computer Interaction, Vol. 9, No. 4, pp.325342.

Chan, Y.E. and Reich, B.H. (2007) 'IT alignment: what have we learned?', Journal of Information

Technology, Vol. 22, No. 4, pp.297-315.

Child, J. (1972) 'Organisational structure, environment and performance: the role of strategic choice', Sociology, Vol. 6, No. 1, pp.1-22.

Daim, T., Basoglu, N. and Tanoglu, I. (2010) 'A critical assessment of information technology adoption: technical, organisational and personal perspectives', International Journal of

Business Information Systems, Vol. 6, No. 3, pp.315-335.

De Sitter, L.U., Den Hertog, J.F. and Dankbaar, B. (1997) 'From complex organisations with simple jobs to simple organisations with complex jobs', Human Relations, Vol. 50, No. 5, pp.497-534.

De Waal, B.M.E. and Batenburg, R.S. (2008) 'Design decisions in workflow management and quality of work', International Journal of Information Systems and Change Management, Vol. 3, No. 4, pp.359-374.

DeJoy, D.M., Wilson, M.G., Vanderberg, R.J., McGrath-Higgins, A.L. and Griffin-Blake, C.S. (2010) 'Assessing the impact of healthy work organization intervention', Journal of Occupational and Organizational Psychology, Vol. 83, No. 1, pp.139-165.

DeLone, W.H. and McLean, E.R. (1992) 'Information systems success: the quest for the dependent variable', Information Systems Research, Vol. 3, No. 1, pp.60-95.

DeLone, W.H. and McLean, E.R. (2003) 'The DeLone and McLean model of information systems success: a ten-year update', Journal of Management Information Systems, Vol. 19, No. 4, pp.9-30.

Dhondt, S., Kraan, K. and Van Sloten, G. (2002) Work Organisation, Technology and Working

Conditions, European Foundation for the Improvement of Living and Working Conditions, Dublin.

Dwivedi, Y., Williams, M.D., Lal, B. and Schwarz, A. (2008) 'Profiling adoption, acceptance and diffusion research in the information systems discipline', Proceedings of the 16th European

Conference on Information Systems, 9-11 June, Galway, Ireland.

Etezadi-Amoli, J. and Farhoomand, A.F. (1996) 'A structural model of end user computing satisfaction and user performance', Information \& Management, Vol. 30, No. 2, pp.65-73. 
Waal, B.M.E. de, Breman, P., Batenburg, R. Do individual characteristics matter? The quality of work during the implementation of a workflow management system in a Dutch social insurance company. International Journal of Business Information Systems: 2012, 11(1), 1-21

Freudenthal, D. (2001) 'Age differences in the performance of information retrieval tasks', Behaviour \& Information Technology, Vol. 20, No. 1, pp.9-22.

Gefen, D. and Straub, D.W. (1999) 'Gender differences in the perception and use of e-mail: an extension to the technology acceptance model', MIS Quarterly, Vol. 21, No. 4, pp.389_ 400.

Gillard, H., Mitev, N. and Scott, S. (2007) 'ICT inclusion and gender: tensions in narratives of network engineer training', Information Society, Vol. 23, No. 1, pp.19-37.

Gittell, J.H., Seidner, R. and Wimbush, J. (2010) 'A relational model of how highperformance work systems work', Organization Science, Vol. 21, No. 2, pp.490-506.

Gomez, L.M., Egan, D.E. and Bowers, C. (1986) 'Learning to use a text editor: some learner characteristics that predict success', Human Computer Interaction, Vol. 2, No. 1, pp.1-23.

$\mathrm{Ha}$, I., Yoon, Y. and Choi, M. (2007) 'Determinants of adoption of mobile games under mobile broadband wireless access environment', Information \& Management, Vol. 44, No. 3, pp.276-286.

Hacker, W. (1989) Vollständige vs. unvollständige arbeitstätigkeiten. Arbeits - und Organisationspsychologie, Psychologie Verlags Union, München.

Hardwick, D. and Salaff, J. (2003) 'Managing work-family boundaries: how do teleworkers make it work?', Paper presented at the Academic Conference Series on Work and Family Business and

Professional Women's Foundation and the Community, Families \& Work Program, Orlando, FL.

Holden, R.J., Brown, R.L., Alper, S.J., Scanlon, M.C., Patel, N.R. and Karsh, B-T. (2011) 'That's nice, but what does IT do? Evaluating the impact of bar coded medication administration by measuring changes in the process of care', International Journal of Industrial Ergonomics, Vol. 41, No. 4, pp.370-379.

Igbaria, M. and Tan, M. (1997) 'The consequences of information technology acceptance on subsequent individual performance', Information \& Management, Vol. 32, No. 3, pp.113121.

Im, I., Kim, Y. and Han, H-J. (2008) 'The effect of perceived risk and technology type on users' acceptance of technologies', Information \& Management, Vol. 45, No. 1, pp.1-9.

Johnson, R.D. and Marakas, G.M. (2000) 'Research report: the role of behavioural modelling in computer skills acquisition: toward refinement of the model', Information Systems Research, Vol. 11, No. 4, pp.418-427.

Josten, E.J.C. and Ester, P. (2005) Quality of Work Life and Work Transitions, OSAPublication A213, Tilburg.

Kamhawi, E.M. and Gunasekaran, A. (2009) 'ERP systems implementation success factors: IS and non-IS managers' perceptions', International Journal of Business Information Systems, Vol. 4, No. 6, pp.688-704.

Kanji, G.K. and Chopra, P.K. (2009) 'Psychosocial system for work well-being: on measuring work stress by causal pathway', Total Quality Management, Vol. 20, No. 5, pp.563-580.

Karasek R. and Theorell, T. (1990) Healthy Work: Stress, Productivity, and the Reconstruction of

Working Life, Basic Books, New York.

Karasek, R.A. (1979) 'Job demands, job decision latitude and mental strain: implications for job redesign', Administrative Science Quarterly, Vol. 24, No. 2, pp.285-308.

Keramati, A. and Behmanesh, I. (2010) 'Assessing the impact of information technology on firm performance using canonical correlation analysis', International Journal of Business Information Systems, Vol. 6, No. 4, pp.497-513.

Kern, H. and Schumann, M. (1984) Das ende der arbeitsteilung?, Beck, München.

Kim, S. (2009) 'IT employee job satisfaction in the public sector', International Journal of Public

Administration, Vol. 32, No. 12, pp.1070-1097.

Kim, S.H. (2008) 'Moderating effects of job relevance and experience on mobile wireless technology acceptance: adoption on a smart phone by individuals', Information \& Management, Vol. 45, No. 6, pp.387-393.

Lawler, E.K., Hedge, A. and Pavlovic-Veselinovic, S. (2011) 'Cognitive ergonomics, sociotechnical systems, and the impact of healthcare information technologies', International Journal of Industrial Ergonomics, Vol. 41, No. 4, pp.336-344. 
Waal, B.M.E. de, Breman, P., Batenburg, R. Do individual characteristics matter? The quality of work during the implementation of a workflow management system in a Dutch social insurance company. International Journal of Business Information Systems: 2012, 11(1), 1-21

Lee, S.M., Kim, I., Rhee, S. and Trimi, S. (2006) 'The role of exogenous factors in technology acceptance of object-oriented technology', Information \& Management, Vol. 43, No. 4, pp.469-480.

Lucas, H.C. Jr. and Spitler, V.K. (1999) 'Technology use and performance: a field study of broker workstations', Decision Sciences, Vol. 30, No. 2, pp.291-311.

Mao, E. and Palvia, P. (2008) 'Exploring the effect of direct experience on IT use: an organisational field study', Information \& Management, Vol. 45, No. 4, pp.249-256.

Medcof, J.W. (1996) 'The job characteristics of computing and non-computing work activities', Journal of Occupational \& Organisational Psychology, Vol. 69, No. 2, pp.199212.

Morris, M.G. and Venkatesh, V. (2010) 'Job characteristics and job satisfaction: understanding the role of enterprise resource planning system implementation', MIS Quarterly, Vol. 34, No. 1, pp.143-161.

Nabitz, U., Jansen, P., Van der Voet, S. and Van den Brink, W. (2009) 'Psychosocial work conditions and work stress in an innovating addiction treatment centre. Consequences for the EFQM excellence model', Total Quality Management, Vol. 20, No. 3, pp.267-281.

Newton, C.J. and Jimmieson, N.L. (2009) 'Subjective fit with organizational culture: an investigation of moderating effects in the work stressor-employee adjustment relationship', The International Journal of Human Resource Management, Vol. 20, No. 8, pp.1770-1789.

Ngai, E.W.T., Leung, C.H. and Wong, Y.C. (2005) 'Application of the workflow management system in electronic commerce: a case study', International Journal of Business Information

Systems, Vol. 1, Nos. 1/2, pp.182-198.

Nickel, G.S. and Pinto, J.N. (1986) 'The computer attitude scale', Computers in Human Behavior, Vol. 2, No. 4, pp.301-306.

Orlikowski, W.J. and Baroudi, J.J. (1991) 'Studying information technology in organisations: research approaches and assumptions', Information Systems Research, Vol. 2, No. 1, pp.1-28.

Poelmans, S. (2002) 'Making workflow systems work: an investigation into the importance of task-appropriation fit, end user support and other technological characteristics', Doctoral dissertation series, Faculty of Economics and Applied Economics, Series No. 161, Katholieke Universiteit Leuven, Belgium.

Ramayah, T., Roy, M.R., Arokiasamy, S., Zbib, I. and Ahmed, Z.U. (2007) 'Critical success factors for successful implementation of enterprise resource planning systems in manufacturing organisations', International Journal of Business Information Systems, Vol. 2, No. 3, pp.276-297.

Roach, D., McGaughey, R.E. and Downey, P.A. (2011) 'Gender within the IT major - a retrospective study of factors that lead students to select an IT major', International Journal of

Business Information Systems, Vol. 7, No. 2, pp.149-165.

Schouteten, R. and Benders, J. (2004) 'Lean production assessed by Karasek's job demand job control model', Economic and Industrial Democracy, Vol. 25, No. 3, pp.347-373.

Schouteten, R.L.J. (2001) Balances in Well-Being at Work: Measurements, Determinants and

Improvements of the Quality of Working Life, Labyrint Publication, Cappelle a/d IJssel.

Scott, J.E. and Walczak, A. (2009) 'Cognitive engagement with a multimedia ERP training tool: assessing computer self-efficacy and technology acceptance', Information \& Management, Vol. 46, No. 4, pp.221-232.

Seddon, P.B. and Kiew, M.Y. (1996) 'A partial test and development of DeLone and McLean's model of IS success', Australasian Journal of Information Systems, Vol. 4, No. 1, pp.90-109.

Sharma, S., Durand, R.M. and Gur-Arie, O. (1981) 'Identification and analysis of moderator variables', Journal of Marketing Research, Vol. 18, No. 3, pp.291-300.

Shaw, L.H. and Gant, L.M. (2002) 'Users divided? Exploring the gender gap in internet use', Cyber

Psychology \& Behavior, Vol. 5, No. 6, pp.517-527. 
Waal, B.M.E. de, Breman, P., Batenburg, R. Do individual characteristics matter? The quality of work during the implementation of a workflow management system in a Dutch social insurance company. International Journal of Business Information Systems: 2012, 11(1), 1-21

Shaw, N.C., DeLone, W.H. and Niederman, F. (2002) 'Sources of dissatisfaction in end user support: an empirical study', The Data Base for Advances in Information Systems, Vol. 33, No. 2, pp.41-56.

Silvius, A.J.G., De Waal, B.M.E. and Smit, J. (2009) 'Business and IT alignment: answers and remaining questions', Proceedings of the 13th Pacific Asia Conference on Information

Systems (PACIS), 10-12 July, Hyderabad, India.

Smulders, P.G.W. (Ed.) (2006) Worklife in the Netherlands, TNO Work \& Employment, Hoofddorp.

Steijn, B. (2001) 'Work systems, quality of working life and attitudes of workers: an empirical study towards the effects of team and non-teamwork', New Technology, Work, and Employment, Vol. 16, No. 3, pp.191-203.

Torkzadeh, R., Pflughoeft, K. and Hall, L. (1999) 'Computer self-efficacy, training effectiveness and user attitudes: an empirical study', Behavior and Information Technology, Vol. 18, No. 4, pp.299-309.

Ugrin, J.C. (2009) 'The effect of system characteristics, stage of adoption, and experience on institutional explanations for ERP systems choice', Accounting Horizons, Vol. 23, No. 4, pp.365-389.

Van Vuuren, T., Smulders, P. and Korver, T. (2006) 'VDU-work and working at home and working from home', in Smulders, P.G.W. (Ed.): Worklife in the Netherlands, pp.125-140, TNO Work \& Employment, Hoofddorp.

Venkatesh, V. and Morris, M.G. (2000) 'Why don't men ever stop to ask for directions? Gender, social influence, and their role in technology acceptance and usage behaviour', MIS Quarterly, Vol. 24, No. 1, pp.115-139.

Venkatesh, V., Morris, M.G., Davis, G.B. and Davis, F.D. (2003) 'User acceptance of information technology: toward a unified view', MIS Quarterly, Vol. 27, No. 3, pp.425-478.

Ward, K.W., Brown, S.A. and Massey, A.P. (2005) 'Organisational influences on attitudes in mandatory system use environments: a longitudinal study', International Journal of Business

Information Systems, Vol. 1, Nos. 1/2, pp.9-30.

Webster, J. and Martocchio, J.J. (1992) 'Microcomputer playfulness: development of a measure with workplace implications', MIS Quarterly, Vol. 16, No. 2, pp.201-266.

Wilkin, C.L. (2007) 'Evaluating the quality of delivered systems: a framework and instrument', International Journal of Business Information Systems, Vol. 2, No. 2, pp.127-148.

Wilson-Evered, E. and Härtel, C.E.J. (2009) 'Measuring attitudes to HRIS implementation: a field study to inform implementation methodology', Asia Pacific Journal of Human Resources, Vol. 47, No. 3, pp.374-384.

Zauchner, S., Korunka, C., Weiss, A. and Kafka-Lützow, A. (2000) 'Gender-related effects of information technology implementation', Gender and Information Technology, Vol. 7, No. 2, pp.119-132.

Zmud, R.W. (1979) 'Individual differences and MIS success: a review of the empirical literature', Management Science, Vol. 25, No. 10, pp.966-979.

Zuboff, S. (1984) In the Age of the Smart Machine: The Future of Work and Power, Basic Books, New York.

Zur Mühlen, M. (2004) Workflow-Based Process Controlling, Logos Verlag, Berlin. 
Waal, B.M.E. de, Breman, P., Batenburg, R. Do individual characteristics matter? The quality of work during the implementation of a workflow management system in a Dutch social insurance company. International Journal of Business Information Systems: 2012, 11(1), 1-21

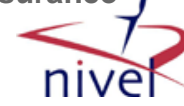

\section{TABLES}

Figure 1 Conceptual model of user satisfaction, the individual characteristics of users and quality of work

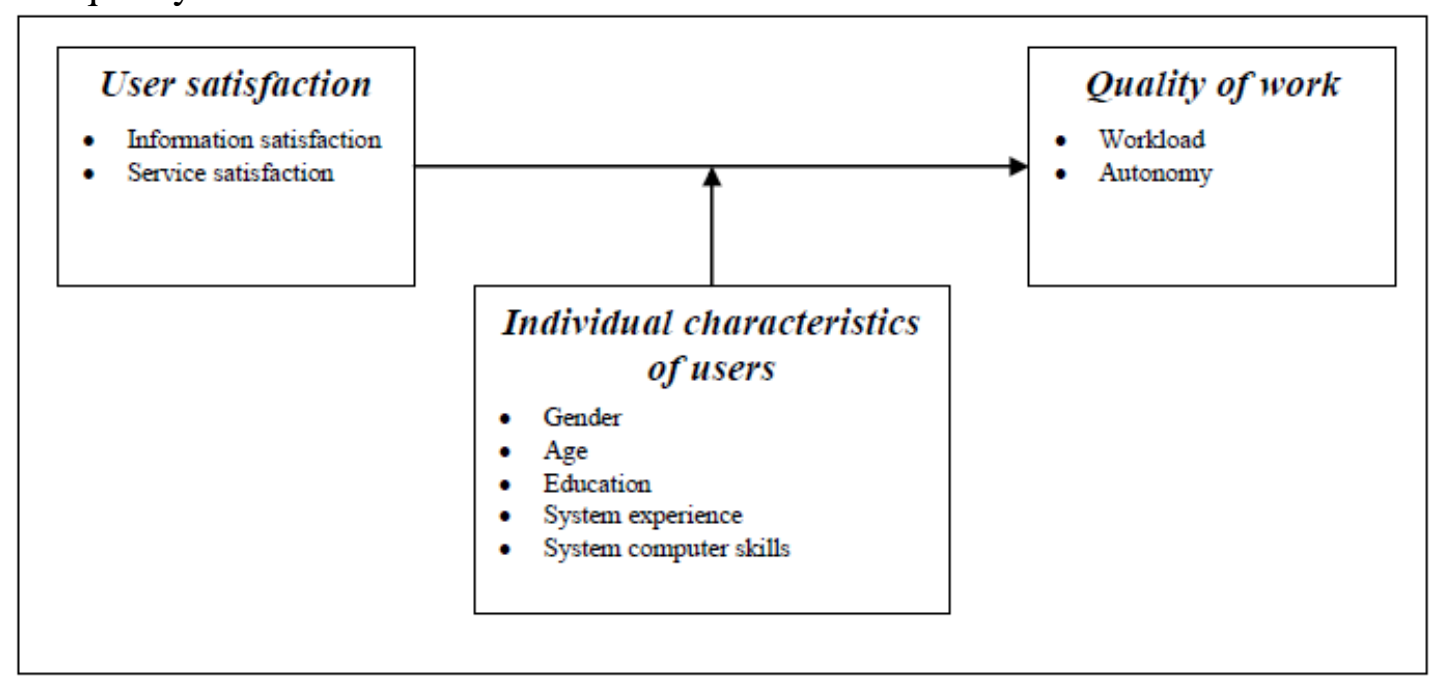

Table 1 User satisfaction factor loadings by item $(N=143)$

\begin{tabular}{llcc}
\hline Nr. & \multicolumn{1}{c}{ Item } & $\begin{array}{c}\text { Information } \\
\text { satisfaction }\end{array}$ & $\begin{array}{c}\text { Service } \\
\text { satisfaction }\end{array}$ \\
\hline F01 & $\begin{array}{l}\text { My relationship with the service desk staff concerning the } \\
\text { WFM system is good. }\end{array}$ & 0.323 & 0.860 \\
F02 & $\begin{array}{l}\text { The attitude of the service desk staff to the user } \\
\text { organisation concerning the WFM system is positive. } \\
\text { The speed of responses to requests for services related to } \\
\text { the WFM system is good. }\end{array}$ & 0.315 & 0.435 \\
F04 $\begin{array}{l}\text { The quality of the responses to requests for services } \\
\text { related to the WFM system is good. }\end{array}$ & 0.336 \\
F05 & $\begin{array}{l}\text { The information that is generated from the WFM system } \\
\text { is relevant. }\end{array}$ & 0.790 \\
F06 & $\begin{array}{l}\text { The information that is generated from the WFM system } \\
\text { is accurate. }\end{array}$ & 0.950 & 0.434 \\
F07 $\quad \begin{array}{l}\text { The information that is generated from the WFM system } \\
\text { is complete. }\end{array}$ & 0.923 & 0.386 \\
F08 $\quad \begin{array}{l}\text { The information that is generated from the WFM system } \\
\text { is reliable. }\end{array}$ & 0.908 & 0.372 \\
\hline
\end{tabular}


Waal, B.M.E. de, Breman, P., Batenburg, R. Do individual characteristics matter? The quality of work during the implementation of a workflow management system in a Dutch social insurance company. International Journal of Business Information Systems: 2012, 11(1), 1-21

Table 2 Quality of work factor loading by dimension and item $(N=143)$

\begin{tabular}{llcc}
\hline No. & \multicolumn{1}{c}{ Item } & Workload & Autonomy \\
\hline Q01 & I have to work very quickly. & 0.781 & -0.245 \\
Q02 & I have a lot of work to do. & 0.695 & -0.026 \\
Q03 & I have to work extra hard to get anything done. & 0.760 & -0.295 \\
Q04 & I work under time pressure. & 0.795 & -0.258 \\
Q05 & I must hurry in my work. & 0.857 & -0.273 \\
Q06 & I can do my work at my ease. & 0.708 & -0.140 \\
Q07 & I can work slowly and finish my work. & 0.748 & -0.092 \\
Q08 & I am free to carry out my work. & -0.265 & 0.766 \\
Q09 & I have an influence over the planning of my work. & -0.065 & 0.721 \\
Q10 & I have an influence over the pace of my work. & -0.372 & 0.628 \\
Q11 & I determine how I perform my work. & -0.202 & 0.723 \\
Q12 & I determine the order of my work. & -0.256 & 0.768 \\
Q13 & I determine how much time I spend on an activity. & -0.192 & 0.631 \\
Q14 & I organise my work by myself. & 0.052 & 0.725 \\
\hline
\end{tabular}

Table 3 Intercorrelations among study variables

\begin{tabular}{|c|c|c|c|c|c|c|c|c|c|c|c|c|}
\hline \multicolumn{2}{|c|}{ Variable } & \multirow{2}{*}{$\frac{\text { Mean }}{2.12}$} & \multirow{2}{*}{$\begin{array}{r}S . D . \\
.62\end{array}$} & \multirow{2}{*}{$\begin{array}{l}1 \\
1\end{array}$} & \multirow[t]{2}{*}{2} & \multirow[t]{2}{*}{3} & \multirow[t]{2}{*}{4} & \multirow[t]{2}{*}{5} & \multirow[t]{2}{*}{6} & \multirow[t]{2}{*}{7} & \multirow[t]{2}{*}{8} & \multirow[t]{2}{*}{9} \\
\hline 1 & $\begin{array}{l}\text { Information } \\
\text { satisfaction }\end{array}$ & & & & & & & & & & & \\
\hline \multirow[t]{2}{*}{2} & \multirow{2}{*}{$\begin{array}{l}\text { Service } \\
\text { satisfaction }\end{array}$} & \multirow[t]{2}{*}{2.43} & \multirow[t]{2}{*}{.56} & .45 & \multirow[t]{2}{*}{1} & & & & & & & \\
\hline & & & & .00 & & & & & & & & \\
\hline \multirow[t]{2}{*}{3} & \multirow[t]{2}{*}{ Workload } & \multirow[t]{2}{*}{2.77} & \multirow[t]{2}{*}{.52} & -.30 & -.33 & 1 & & & & & & \\
\hline & & & & .00 & .00 & & & & & & & \\
\hline \multirow[t]{2}{*}{4} & \multirow[t]{2}{*}{ Autonomy } & \multirow[t]{2}{*}{2.82} & \multirow[t]{2}{*}{.41} & .22 & .26 & -.27 & \multirow[t]{2}{*}{1} & & & & & \\
\hline & & & & .01 & .00 & .00 & & & & & & \\
\hline \multirow[t]{2}{*}{5} & \multirow[t]{2}{*}{ Gender } & \multirow[t]{2}{*}{1.40} & \multirow[t]{2}{*}{.49} & .06 & .14 & -.10 & .09 & 1 & & & & \\
\hline & & & & .52 & .09 & .22 & .29 & & & & & \\
\hline \multirow[t]{2}{*}{6} & \multirow[t]{2}{*}{ Age } & \multirow[t]{2}{*}{48.5} & \multirow[t]{2}{*}{7.99} & -.19 & -24 & .26 & -.24 & -.38 & 1 & & & \\
\hline & & & & .02 & .00 & .00 & .00 & .00 & & & & \\
\hline 7 & Education & 2.80 & .98 & -.33 & -.13 & .11 & -.26 & -.10 & .22 & 1 & & \\
\hline & & & & .00 & .13 & .19 & .00 & .24 & .01 & & & \\
\hline 8 & System & 10.4 & 7.81 & .17 & .12 & .01 & -.02 & .00 & .02 & -.17 & 1 & \\
\hline & experience & & & .04 & .17 & .96 & .81 & .96 & .81 & .04 & & \\
\hline 9 & System & 3.07 & .87 & .14 & .14 &,- 16 & .19 & -.02 & -.14 & -.05 & .35 & 1 \\
\hline & $\begin{array}{l}\text { computer } \\
\text { skills }\end{array}$ & & & .11 & .10 & .06 & .02 & .85 & .11 & .55 & .00 & \\
\hline
\end{tabular}

Note: Italic is significant at .05 or lower 
Waal, B.M.E. de, Breman, P., Batenburg, R. Do individual characteristics matter? The quality of work during the implementation of a workflow management system in a Dutch social insurance company. International Journal of Business Information Systems: 2012, 11(1), 1-21

Table 4 Regression analyses: predictive power of user satisfaction and quality of work for gender $(N=143)$

\begin{tabular}{lcccccc}
\hline & \multicolumn{2}{c}{ Workload } & & \multicolumn{2}{c}{ Autonomy } \\
\cline { 2 - 3 } & Coefficient & $p$ & & Coefficient & $p$ \\
\hline Information satisfaction $\left(\beta_{1}\right)$ & -.22 & .03 & & .18 & .10 \\
Information satisfaction $\times$ Gender $\left(\beta_{2}\right)$ & -.12 & .25 & & .08 & .48 \\
Service satisfaction $\left(\beta_{1}\right)$ & -.28 & .01 & & .22 & .03 \\
Service satisfaction $\times$ Gender $\left(\beta_{2}\right)$ & -.09 & .39 & & .05 & .61 \\
\hline
\end{tabular}

Table 5 Regression analyses: predictive power of user satisfaction and quality of work for age $(N=143)$

\begin{tabular}{lcccccc}
\hline & \multicolumn{2}{c}{ Workload } & & \multicolumn{2}{c}{ Autonomy } \\
\cline { 2 - 3 } & Coefficient & $p$ & & Coefficient & $p$ \\
\hline Information satisfaction $\left(\beta_{1}\right)$ & -.57 & .00 & & .45 & .00 \\
Information satisfaction $\times$ Age $\left(\beta_{2}\right)$ & .32 & .02 & & -.27 & .06 \\
Service satisfaction $\left(\beta_{1}\right)$ & -.55 & .00 & & .47 & .00 \\
Service satisfaction $\times$ Age $\left(\beta_{2}\right)$ & .27 & .02 & & -.28 & .02 \\
\hline
\end{tabular}

Table 6 Regression analysis: predictive power of user satisfaction and quality of work for education $(N=143)$

\begin{tabular}{lcccccc}
\hline & \multicolumn{2}{c}{ Workload } & & \multicolumn{2}{c}{ Autonomy } \\
\cline { 2 - 3 } \cline { 5 - 6 } & Coefficient & $p$ & & Coefficient & $p$ \\
\hline Information satisfaction $\left(\beta_{1}\right)$ & -.31 & .00 & & .30 & .00 \\
Information satisfaction $\times$ Education $\left(\beta_{2}\right)$ & .03 & .76 & & -.16 & .08 \\
Service satisfaction $\left(\beta_{1}\right)$ & -.36 & .00 & & .36 & .00 \\
Service satisfaction $\times$ Education $\left(\beta_{2}\right)$ & .07 & .42 & & -.24 & .01 \\
\hline
\end{tabular}

Table 7 Regression analysis: predictive power of user satisfaction and quality of work for system experience $(N=143)$

\begin{tabular}{lccrcrl}
\hline & \multicolumn{2}{c}{ Workload } & & \multicolumn{2}{c}{ Autonomy } \\
\cline { 2 - 2 } \cline { 6 - 6 } & Coefficient & $p$ & & Coefficient & $p$ \\
\hline Information satisfaction $\left(\beta_{1}\right)$ & -.33 & .00 & .26 & .01 \\
Information satisfaction $\times$ System experience $\left(\beta_{2}\right)$ & .07 & .46 & & -.08 & .41 \\
Service satisfaction $\left(\beta_{1}\right)$ & -.34 & .00 & .28 & .00 \\
Service satisfaction $\times$ System experience $\left(\beta_{2}\right)$ & .03 & .72 & & -.06 & .50 \\
\hline
\end{tabular}


Waal, B.M.E. de, Breman, P., Batenburg, R. Do individual characteristics matter? The quality of work during the implementation of a workflow management system in a Dutch social insurance company. International Journal of Business Information Systems: 2012, 11(1), 1-21

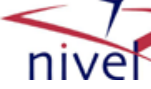

Table 8 Regression analysis: predictive power of user satisfaction and quality of work for system computer skills $(N=143)$

\begin{tabular}{lccccc}
\hline & \multicolumn{2}{c}{ Workload } & & \multicolumn{2}{c}{ Autonomy } \\
\cline { 2 - 3 } \cline { 6 - 6 } & Coefficient & $p$ & Coefficient & $p$ \\
\hline Information satisfaction $\left(\beta_{1}\right)$ & -.21 & .10 & .09 & .47 \\
Information satisfaction $\times$ System computer skills $\left(\beta_{2}\right)$ & -.12 & .33 & .18 & .16 \\
Service satisfaction $\left(\beta_{1}\right)$ & -.24 & .03 & .13 & .25 \\
Service satisfaction $\times$ System computer skills $\left(\beta_{2}\right)$ & -13 & .22 & .20 & .08 \\
\hline
\end{tabular}

